\section{The impact of compulsory hygiene training given to employees working in the sector of food and beverages services on their hygiene- related habits, behaviours and knowledge}

\author{
Ümit Sormaz ${ }^{1}$ \\ Nevin Şanlıer ${ }^{2}$
}

\section{Zorunlu hijyen eğitiminin yiyecek içecek hizmetleri personelinde hijyen alışkanlıklarına, davranışlarına ve bilgi düzeylerine etkisi}

\begin{abstract}
Food and beverages companies constituse one of the most important shares of servise industry, the number of food and beverages companies has been increasing every other day. Food workers carry responsibilities concerning human helat. This study has been carried out to detect the impact of the compulsory hygiene training given to the food and beverages services personnel on the hygiene-related habits and behaviours of the employees, and within the scope of the regulation of "Hygiene Education Program" which was published on the official gazetta and put into force being signed by 4 ministries. 1150 food and beverages sector personnel who participated in the hygiene training offered in İstanbul to tourism sector stuff and were volunteer to participate were included in the study. Hygiene-related habits and behaviours before the training and knowledge levels were found to be increasing statistically meaningfully after the study $(\mathrm{p}<0,01)$.
\end{abstract}

As a result, it was found out that the compulsory hygiene training given to the food and beverages sector personnel affects employees' hygiene-related habits, behaviours, and knowledge levels positively. It has been
Özet

Hizmet endüstrisinin en önemli paydaşlarından biri olan yiyecek içecek işletmelerinin sayısı her geçen gün artmaktadır. Gıda sektörü ile uğraşan personel, insan sağllğ̆1 yönünden sorumluluk taşımaktadır.

$\mathrm{Bu}$ araştırma, ülkemizde dört bakanlığın kat1limiyla imzalanarak Resmi Gazete'de yayımlanan ve yürürlüğe giren "Hijyen Eğitim Programı" Yönetmeği kapsaminda yiyecek içecek hizmetleri personeline verilen zorunlu hijyen eğitiminin çalışanların hijyen alışkanlıkları ve davranışlarına olan etkisini tespit etmek amaciyla yürütülmüștür.

Araştırmaya, İstanbul'da turizm sektöründe çalışan personele verilen hijyen eğitimlerine katılan gönüllü 1150 yiyecek içecek hizmetleri personeli dahil edilmiştir. Eğitim öncesi hijyen alışkanlıklarının davranışlarının ve eğitim sonrası hijyen bilgi düzeylerinin eğitim öncesine göre istatistiksel olarak anlamlı yönde arttığ1 saptanmiştır $(\mathrm{p}<0.01)$.

Sonuçta yiyecek içecek hizmetleri bölümü çalışanlarına verilen zorunlu hijyen eğitiminin, personelin hijyen alışkanlıkları, hijyen davranışlar1 ve hijyen bilgi düzeylerine olan olumlu etkisi tespit edilmiştir. Yiyecek içecek hizmetleri sektöründe çalışan personele verilecek

\footnotetext{
1 Assist. Prof. Dr., University of Necmettin Erbakan, Faculty of Tourism, Department of Gastronomy and Culinary Arts, usormaz@,konya.edu.tr

2 Prof. Dr., University of Gazi, Faculty of Health Sciences, Department of Nutrition and Dietetics, nevintekgul@gmail.com
} 
Sormaz, Ü., \& Şanlıer, N. (2017). Zorunlu hijyen eğitiminin yiyecek içecek hizmetleri personelinde hijyen alışkanlıklarına, davranışlarına ve bilgi düzeylerine etkisi. Journal of Human Sciences, 14(2), 1356-1369. doi:10.14687/jhs.v14i2.4545

discovered that the training given to the staff working in food and beverage companies does increase the level of knowledge in hygiene.

Keywords: Tourism; Kitchen Stuff; Hygiene; Hygiene Regulations; Hygiene Training.

(Extended English abstract is at the end of this document) hijyen eğitim programlarının, personelin hijyen bilgi düzeyini arttırdığı belirlenmiştir.

Anahtar Kelimeler: Turizm; Mutfak Çalışanları; Hijyen; Hijyen Yönetmeliği; Hijyen Eğitimi.

\section{Giriş}

Enfeksiyonların, tüm dünyada en önemli mortalite ve morbidite kaynağ1 olarak kabul edilmesi ve özellikle besin üretim ve servis alanlarında denetim imkanlarının artmasıyla beraber işletmelerde gıda güvenliği ve hijyen kavramına daha fazla önem verilmesini sağlamıştır (CDC, 2002; WHO, 2006a; Tayar, 2011). "Gıda zinciri boyunca oluşabilecek biyolojik, kimyasal veya fiziksel tehlikelerden ve kirlenmelerden gidaların korunması ve gidaların tüketici sağlığına zarar vermeyeceğini teminat altına almak" olarak tanımlanan gıda güvenliği zaman zaman hijyen tanımı olarak kullanılsa da kısaca hijyen "sağlığı korumak amaciyla uygulanan ilkeler" olarak tanımlanmaktadır. Personel hijyeni ise "personelin vücut temizliği’" şeklinde tanımlamak mümkündür (WHO, 2006b; Kozak, 2008).

Günümüzde tüm dünya ülkelerinde önemli halk sağlığ1 sorunu olan insan kaynaklı enfeksiyon ve besin zehirlenmeleri işyerinde çalışan personelin sağlı̆̆ ile yakından ilgilidir (Kozak vd., 2008; Koçoğlu vd., 2004; Temelli, 2002). Gıda işleyicileri arasında gida kaynaklı hastalıkların oluşmasındaki en çok rapor edilen durumlardan olan personel hijyeni eksikliği birçok ülkede halk sağllğı için tehdit oluşturmaktadır (Dominguez vd., 2002; Eksen vd., 2004; Ünlüönen ve Cömert, 2013). Özellikle gelişmekte olan ülkelerde sorunun boyutlarının daha büyük olduğu ve buralarda yetişkin ölümlerinin yarıya yakınının besin kaynaklı enfeksiyöz ve paraziter hastalıklara bağlı olduğu bildirilmektedir (Koçoğlu vd., 2004).

İnsan yaşamının her alanında önemli olan hijyen işletmeler için de oldukça önem taşımaktadır. Tüketicilerin hijyen konusunda eğitim ve bilinçlenme düzeyinin artması, yiyecek içecek işletmelerinde sunulan mutfak ve servis hizmetlerinin hijyen kurallarına uyularak temiz, özenli ve estetik değerlere uygun olması vb. nedenlerle hijyenin önemi tüketicilerin beklentileri arasında üst sıralara çıkmakta ve günümüzde bir kalite göstergesi olarak görülmesine neden olmaktadır (Tayar, 2011). Benzer şekilde personel hijyenine gösterilen özenin yanı sıra personelin iş elbiselerinin ve çalışrken giyilen kep, eldiven, maske gibi diğer malzemelerin temizlenmesi de önemli görülmektedir (Atasever, 2000). Son günlerde, hijyen eğitimi konusunda literatürde bir çok çalışmaya rastlanmaktadır (Thakker ve Jadhav, 2015; Theriault vd., 2015; Issa vd., 2015; Sansam vd., 2016; Arboqast vd., 2016).

Gıdanın hazırlığı, dikkatsiz saklama ve zayıf hijyen koşulları nedeniyle gıda zehirlenmelerinin ortaya çıkması kaçınılmaz olup gıda üreticilerinin doğru bir hijyen anlayışını benimsemeleri, bu konuda ilerleme sağlanabilmesinde mümkün olacak ve bu ilerleme neticesinde de gida zehirlenmesine bağlı rahatsızlıklarda azalma sağlayacaktır (Clayton vd., 2002; Lucca ve Torres, 2006). Gıda zehirlenmesine neden olan hastalıkları engellemek için yiyecek içecek hizmetlerinde çalışan personelin gösterecekleri çaba ahlaki ve yasal bir sorumluluk olup bunu başarmanın başlıca yolu personel hijyenine gereken önemi vermektir. Bu konuda, işletme yöneticisinin hijyen konusunda bilinçli olması ve çalısanlarının düzenli eğitimler almasını teşvik etmesi ile hijyenin önemli olduğu bilincinin çalışanlarına kazandırılmasını sağlaması gerekmektedir (Baş vd., 2006). Bu nedenle; Milli Eğitim Bakanlığı, Sağlık Bakanlığ1 ve Gıda, Tarım ve Hayvancılık Bakanlığı ile Türkiye Esnaf ve Sanatkârları Konfederasyonu ve Türkiye Odalar ve Borsalar Birliği tarafindan kurulan 
Sormaz, Ü., \& Șanlıer, N. (2017). Zorunlu hijyen eğitiminin yiyecek içecek hizmetleri personelinde hijyen alıșkanlıklarına, davranışlarına ve bilgi düzeylerine etkisi. Journal of Human Sciences, 14(2), 1356-1369. doi:10.14687/jhs.v14i2.4545

komisyonca. 5 Temmuz 2013 tarih ve 28698 sayll Resmi Gazete’ de yayımlanarak yürürlüğe giren 40 saatlik "Hijyen Eğitimi Yönetmeliği" nin yiyecek içecek hizmetlerinde çalışan personele uygulanması zorunlu kılınmıştır.

\section{Amaç}

Günümüzde mesleklerin değişim ile karşı karşıya olması ve daha karmaşık bir yapıda bulunmaya başlaması, meslekî yeterliklerin de geniş tabanlı bilgilere, becerilere ve tavırlara dayalı olmasını ve programların buna göre geliştirilmesini zorunlu hâle getirmektedir (MEB, 2013). Bu araştırma, turizm sektöründe çalısan yiyecek içecek hizmetleri personeline verilen zorunlu hijyen eğitiminin çalşsanların hijyen alışkanlıkları ve davranışlarına etkisini araştırmak amacıyla yürütülmüştür.

\section{Yöntem ve Materyal}

\subsection{Araştırmanın Yeri ve Zamanı}

Bu araştırma, İstanbul'da faaliyet gösteren turizm işletmelerinde çalışan ve çalışmaya istekli olarak katılan personel ile 1 Şubat-1 Ekim 2015 tarihlerinde yürütülmüștür.

\subsection{Nüfus ve Örneklem Seçimi}

Araştırmaya, turizm sektörünün yiyecek içecek departmanında çalışan, verilen hijyen eğitimlerine katılan gönüllü 1150 yiyecek içecek hizmetleri personeli katılmıştır. Araştırmaya, yiyecek içecek hizmetleri alanının altında yer alan meslek dallarına (aşçlık, pastacılık, servis elemanlığı...gibi) ayrilan gruplar dahil edilmiştir.

\subsection{Verilerin Toplanması}

$\mathrm{Bu}$ bölümde; araştırmada boyunca uygulanan veri toplama yöntemi, very toplama arac1, geçerlilik ve güvenilirlik ve verilerin değerlendirilmesi konularına değinilmiştir.

\subsubsection{Veri Toplanma Yöntemi}

Araştırmada, veri toplanması amacıyla nicel araştırma yöntemlerinden anket yöntemi kullanılmıştır. Belli bir amaç ve plana göre düzenlenmiş soru listesi olan anket, genellikle geniş kitlelere uygulanabilen ve sonuçlar üzerinde istatistiki değerlendirme yapılabilen bir araştırma yöntemidir (Karasar, 2003: 174).

\subsubsection{Veri Toplanma Arac1}

Veri toplama aracı olarak birden fazla seçeneği işaretlemenin mümkün olmadığı çoktan seçmeli sorudan oluşan anket, Şanlıer (2009), Memiş (2009) ve Şanlıer vd. (2010) tarafindan geçerlilik ve güvenilirliği test edildikten sonra çalışmalarında kullanılmış sorulardan derlenerek hazırlanmıştır. 1. bölümde katılımcıların demografik bilgileri, 2. bölümde katılımcıların çalıştıkları işletme bilgileri, 3. bölümde katılımcıların hijyen alışkanlıkları, 4. bölümde katılımcıların hijyen davranışları ve 5. bölümde katılımcıların hijyen bilgi düzeylerini belirlemek üzere toplam 5 bölüm ve 38 sorudan oluşan anket formları katılımcılara eğitim öncesi ve sonrasında araştırmacı tarafindan yüz-yüze tekniği kullanılarak uygulanmıştır. Okur-yazar olmayan katılımcılara anketler, araştırmacılar tarafindan anket soruları ve cevapları tek tek okunarak, verdikleri cevapların yine araştırmacılar tarafından işaretlemesi ile uygulanması sağlanmıştır.

\subsubsection{Geçerlilik ve Güvenilirlik}

Bilimsel bir araştırmada yapılan ölçümlerin geçerlilik ve güvenilirlikleri veri toplama aracının en önemli niteliklerinden biri olup veri toplama sürecinde yapilabilecek rastlantısal ve sistematik hatalar çalışmanın geçerliliği ve güvenilirliği üzerinde etkilidir (Ural ve Kılıç, 2013). Sosyal bilimlerde, Alfa yöntemi kullanılarak yapılan güvenilirlik analizi sonucu elde edilen Cronbach Alfa değerinin 0.60'1n üzerinde olduğu durumlarda ölçeğin güvenilir olduğu kabul edilmektedir (Kalayc1, 2009). İslamoğlu ve Alnıç̧1k (2014)'a göre, sosyal bilimler alanında yapılan araştırmalarda Cronbach Alfa değeri;

$$
\text { - } \quad 0,00<\alpha<0,40 \text { ise ölçeğin güvenilirliği yok, }
$$


Sormaz, Ü., \& Șanlıer, N. (2017). Zorunlu hijyen eğitiminin yiyecek içecek hizmetleri personelinde hijyen alıșkanlıklarına, davranışlarına ve bilgi düzeylerine etkisi. Journal of Human Sciences, 14(2), 1356-1369. doi:10.14687/jhs.v14i2.4545

- $\quad 0,41<\alpha<0,60$ ise ölçek güvenilirliği düşük,

- $0,61<\alpha<0,80$ ise kabul edilebilir güvenilirlik,

- $\quad 0,81<\alpha<1,00$ ise ölçek güvenilirliği yüksek

olarak değerlendirilmektedir.

Çalışmamızda kullanılan anketi oluşturan çoktan seçmeli soru ve cevap seçenekleri sayısı her bölümde farklı olduğundan, birinci aşama olarak SPSS istatistik programında anket bölümlerine ayr1 ayrı Alfa yöntemi kullanılarak güvenilirlik analizi uygulanmış, negatif çıkan sorular anket formundan çıkartılmıştır. 2. aşama olarak anketin çıkarılan soruları dışında kalan ve kullanılabilen sorularının tümüne SPSS istatistik programında Alfa yöntemi kullanılarak güvenilirlik analizine tabi tutulmas1 sonucunda Cronbach Alfa değeri 0.68 olarak bulunmuştur. Bu oran, kullanılan ölçeğin Kalayc1 (2009)'ya göre güvenilir düzeyde, İslamoğlu ve Alnıaçı (2014)'a göre kabul edilebilir düzeyde güvenilir olduğunu göstermektedir.

\subsection{Verilerin Değerlendirilmesi}

Elde edilen veriler SPSS 17.0 programında değerlendirilmiş ve yorumlanmıştır. Verilerin değerlendirilmesinde frekans, yüzde alınmış ve istatistiksel değerlendirmesinde "Khi-kare testi" kullanılmıştır (Büyüköztürk, 2004; Eymen, 2007; Ural, 2013).

\section{BULGULAR}

Çalışmaya, İstanbul'da turizm sektöründe çalışan 176 kadın (\%15.3) ve 974 erkek (\%84.7) olmak üzere toplam 1150 (\%100.0) yiyecek-içecek hizmetleri personeli katılmıştır. Çalışmaya katılanların \%30.3'ünün ilkokul mezunu, \%28.6'sının ortaokul mezunu, \%49.0'unun mesleki eğitim almadıkları, \%29.0'unun 11-20 yıl ve \%26.1'inin 5 yıldan daha az süredir sektörde çalıştıkları belirlenmiştir (Tablo 1).

Tablo 1. Demografik Bilgiler

\begin{tabular}{lrr}
\hline \multicolumn{1}{c}{ Genel Bilgiler } & n & \% \\
\hline Cinsiyet & & \\
Erkek & 174 & 84.7 \\
Kadın & & 15.3 \\
\hline Eğitim Durumu & \\
Okur-yazar değil & 47 & 4.1 \\
İlkokul & 349 & 30.3 \\
Ortaokul & 329 & 28.6 \\
Lise & 270 & 23.5 \\
Ön Lisans & 119 & 10.3 \\
Üniversite & 36 & 3.1 \\
\hline Mesleki Eğitim Alma Durumu & & \\
Almayan & 564 & 49.0 \\
Mesleki eğitim merkezinden & 204 & 17.7 \\
Özel kurslardan & 93 & 8.1 \\
Meslek lisesinden & 158 & 13.7 \\
Yüksek okuldan & 97 & 8.4 \\
Üniversiteden & 34 & 3.0 \\
\hline Meslekte Çalıştıkları Süre (Y11) & & \\
5 yldan daha az & 300 & 26.1 \\
6-10 & 116 & 10.1 \\
11-20 & 334 & 29.0 \\
21-30 & 328 & 28.5 \\
31-40 & 62 & 5.4 \\
41 ylldan daha fazla & 10 & 0.9 \\
\hline TOPLAM & $\mathbf{1 1 5 0}$ & $\mathbf{1 0 0 . 0}$ \\
\hline
\end{tabular}


Sormaz, Ü., \& Șanlıer, N. (2017). Zorunlu hijyen eğitiminin yiyecek içecek hizmetleri personelinde hijyen alıșkanlıklarına, davranışlarına ve bilgi düzeylerine etkisi. Journal of Human Sciences, 14(2), 1356-1369. doi:10.14687/jhs.v14i2.4545

Personelin \%73.9'unun otellerde ve \%26.1'inin restoranlarda, \%29.3’ünün 5 yıldızlı otellerde ve \%46.7'sinin mutfak departmanında çalısstıkları \%52.6'sının uluslararası işletmeler oldukları saptanmiştır (Tablo 2).

Tablo 2. İşletme Bilgilerinin Dağılımı

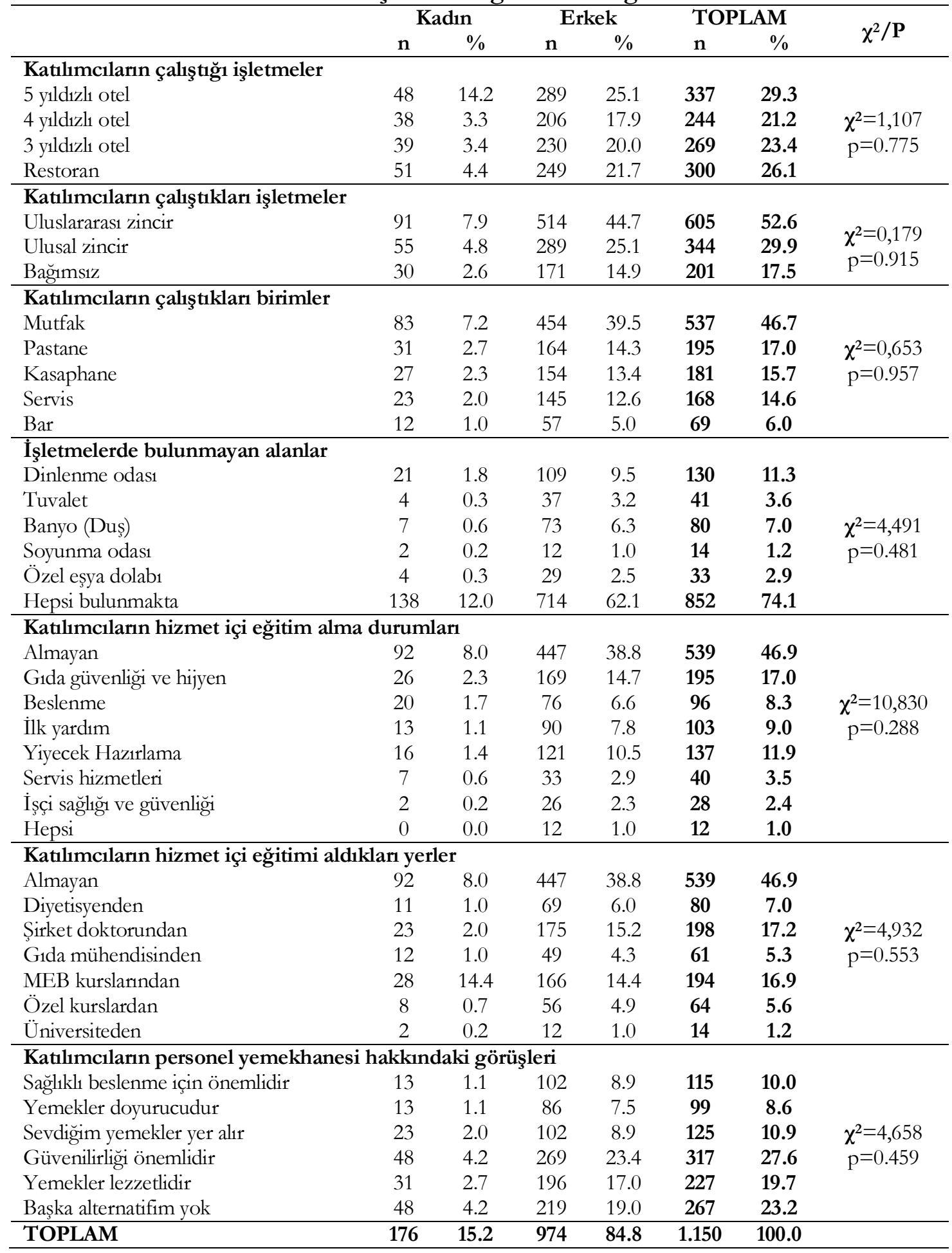

Katılımcıların \%74.1'i çalıştıkları işletmelerde yiyecek-içecek hizmetleri departmanına ait sosyal alanların olmadığını, \%46.9’u mutfak ile ilgili herhangi bir hizmet içi eğitim almadıklarını ve \%17.0'si gıda güvenliği ve hijyen eğitimi aldıklarını bildirmişlerdir (Tablo 2). 
Sormaz, Ü., \& Şanlıer, N. (2017). Zorunlu hijyen eğitiminin yiyecek içecek hizmetleri personelinde hijyen alışkanlıklarına, davranışlarına ve bilgi düzeylerine etkisi. Journal of Human Sciences, 14(2), 1356-1369. doi:10.14687/jhs.v14i2.4545

Tablo 3. Katılımcıların Hijyen Alışkanlıklarının Dağılımı

\begin{tabular}{|c|c|c|c|c|c|c|c|c|c|c|c|c|c|}
\hline \multirow{3}{*}{$\begin{array}{c}\text { PERSONELIN } \\
\text { HİJYEN } \\
\text { ALIŞKANLIKLARI }\end{array}$} & \multicolumn{6}{|c|}{ EĞİTİM ÖNCESİ } & \multicolumn{6}{|c|}{ EĞİTİM SONRASI } & \multirow{3}{*}{$\chi^{2} / \mathbf{P}$} \\
\hline & \multicolumn{2}{|c|}{ Erkek } & \multicolumn{2}{|c|}{ Kadın } & \multicolumn{2}{|c|}{ TOPLAM } & \multicolumn{2}{|c|}{ Erkek } & \multicolumn{2}{|c|}{ Kadın } & \multicolumn{2}{|c|}{ TOPLAM } & \\
\hline & $\mathbf{n}$ & $\%$ & $\mathbf{n}$ & $\%$ & $\mathbf{n}$ & $\%$ & $\mathbf{n}$ & $\%$ & $\mathbf{n}$ & $\%$ & $\mathbf{n}$ & $\%$ & \\
\hline \multicolumn{14}{|c|}{ Ellerin en s1k yıkama zamanlanı } \\
\hline İşe başlarken & 135 & 11.7 & 16 & 1.4 & 151 & 13.1 & 36 & 3.1 & 2 & 0.2 & 38 & 3.3 & \multirow{10}{*}{$\begin{array}{c}\chi^{2}=377,021 \\
\mathrm{p}<0.001\end{array}$} \\
\hline İş bitiminde & 73 & 6.3 & 15 & 1.3 & 88 & 7.7 & 47 & 4.1 & 12 & 1.0 & 59 & 5.1 & \\
\hline Tuvalete girmeden önce & 92 & 8.0 & 17 & 1.5 & 109 & 9.5 & 48 & 4.2 & 7 & 12.7 & 55 & 4.8 & \\
\hline Tuvaletten çı1kınca & 83 & 7.2 & 21 & 1.8 & 104 & 9.0 & 20 & 1.7 & 10 & 0.9 & 30 & 2.6 & \\
\hline Eldiven takmadan önce & 54 & 4.7 & 14 & 1.2 & 68 & 5.9 & 34 & 3.0 & 5 & 0.4 & 39 & 3.4 & \\
\hline $\begin{array}{l}\text { Çiğ besine temastan } \\
\text { sonar }\end{array}$ & 68 & 5.9 & 17 & 1.5 & 85 & 7.4 & 32 & 2.8 & 7 & 0.6 & 39 & 3.4 & \\
\hline Öksürünce/Aksırınca & 27 & 2.3 & 7 & 20.6 & 34 & 3.0 & 10 & 0.9 & 3 & 0.3 & 13 & 1.1 & \\
\hline $\begin{array}{l}\text { Mendil kullandiktan } \\
\text { sonar }\end{array}$ & 41 & 3.6 & 6 & 0.5 & 47 & 4.1 & 18 & 1.6 & 3 & 0.3 & 21 & 1.8 & \\
\hline $\begin{array}{l}\text { Kirli araca temastan } \\
\text { sonar }\end{array}$ & 61 & 5.3 & 6 & 0.5 & 67 & 5.8 & 21 & 1.8 & 1 & 0.1 & 22 & 1.9 & \\
\hline Hepsi & 340 & 29.6 & 57 & 5.0 & 397 & 34.5 & 708 & 61.6 & 126 & 11.0 & 834 & 72.5 & \\
\hline \multicolumn{14}{|c|}{ Ellerin en sık yıkama alanları } \\
\hline Mutfak evyesinde & 491 & 42.7 & 90 & 7.8 & 581 & 50.5 & 87 & 7.6 & 20 & 1.7 & 107 & 9.3 & \multirow{3}{*}{$\begin{array}{c}\chi^{2}=254,088 \\
p<0.001\end{array}$} \\
\hline El y1kama lavabosunda & 281 & 24.4 & 38 & 3.3 & 319 & 27.7 & 750 & 65.2 & 131 & 11.4 & 881 & 76.6 & \\
\hline Tuvaletteki lavaboda & 202 & 17.6 & 48 & 4.2 & 250 & 21.7 & 137 & 11.9 & 25 & 2.2 & 162 & 14.1 & \\
\hline \multicolumn{14}{|c|}{ Elleri yıkamak için en sık kullandıkları temizlik gereç } \\
\hline Katı sabun & 132 & 11.5 & 23 & 2.0 & 155 & 13.5 & 51 & 4.4 & 5 & 0.4 & 56 & 4.9 & \multirow{4}{*}{$\begin{array}{c}\chi^{2}=11,194 \\
p<0.05\end{array}$} \\
\hline Siv1 sabun & 544 & 47.3 & 97 & 8.4 & 641 & 55.7 & 177 & 15.4 & 26 & 2.3 & 203 & 17.7 & \\
\hline Sadece su & 134 & 11.7 & 17 & 1.5 & 151 & 13.1 & 36 & 3.1 & 7 & 0.6 & 43 & 3.7 & \\
\hline Dezenfektanlı siv1 & 164 & 14.3 & 39 & 3.4 & 203 & 17.7 & 710 & 61.7 & 138 & 12.0 & 848 & 73.7 & \\
\hline \multicolumn{14}{|c|}{ Ellerin kurulamak için en sık kullandıkları temizlik yöntemi } \\
\hline Kurulamam & 328 & 28.5 & 62 & 5.4 & 390 & 33.9 & 20 & 1.7 & 7 & 0.6 & 27 & 2.3 & \multirow{6}{*}{$\begin{aligned} \chi^{2} & =21,830 \\
p & =0.646\end{aligned}$} \\
\hline Önlüğüme silerim & 70 & 6.1 & 13 & 1.1 & 83 & 7.2 & 39 & 3.4 & 6 & 0.5 & 45 & 3.9 & \\
\hline Pamuk havlu ile & 230 & 20.0 & 52 & 4.5 & 282 & 24.5 & 45 & 3.9 & 6 & 0.5 & 51 & 4.4 & \\
\hline Kağıt havlu ile & 135 & 11.7 & 17 & 1.5 & 152 & 13.2 & 776 & 67.5 & 143 & 12.4 & 919 & 79.9 & \\
\hline Mutfak bezleri ile & 92 & 8.0 & 11 & 1.0 & 103 & 9.0 & 36 & 3.1 & 7 & 0.6 & 43 & 3.7 & \\
\hline Elektrikli kurutucular ile & 119 & 10.3 & 21 & 1.8 & 140 & 12.2 & 58 & 5.0 & 7 & 0.6 & 65 & 5.7 & \\
\hline \multicolumn{13}{|c|}{ Periyodik sağlık kontrolü yaptırma durumları } & \multirow{6}{*}{$\begin{array}{c}\chi^{2}=14,562 \\
\mathrm{p}=0.557\end{array}$} \\
\hline Yapilmiyor & 426 & 37.0 & 83 & 7.2 & 509 & 44.3 & 86 & 7.5 & 14 & 1.2 & 100 & 8.7 & \\
\hline Ayda bir & 18 & 1.6 & 5 & 0.4 & 23 & 2.0 & 24 & 2.1 & 3 & 0.3 & 27 & 2.3 & \\
\hline Üç ayda bir & 186 & 16.2 & 25 & 2.2 & 211 & 18.3 & 162 & 14.1 & 39 & 3.4 & 201 & 17.5 & \\
\hline Altu ayda bir & 158 & 13.7 & 26 & 2.3 & 184 & 16.0 & 573 & 49.8 & 100 & 8.7 & 673 & 58.5 & \\
\hline Yllda bir & 186 & 16.2 & 37 & 3.2 & 223 & 19.4 & 129 & 11.2 & 20 & 1.7 & 149 & 13.0 & \\
\hline Sigara içme alanlarına & & & & & & & & & & & & & \\
\hline İçmiyorum & 144 & 12.5 & 32 & 2.8 & 176 & 15.3 & 151 & 13.1 & 37 & 3.2 & 188 & 16.3 & \\
\hline Mutfakta & 143 & 12.4 & 16 & 1.4 & 159 & 13.8 & 92 & 8.0 & 16 & 1.4 & 108 & 9.4 & \\
\hline $\begin{array}{l}\text { Personel } \\
\text { yemekhanesinde }\end{array}$ & 204 & 17.7 & 36 & 3.1 & 240 & 20.9 & 127 & 11.0 & 20 & 1.7 & 147 & 12.8 & $\begin{aligned} \chi^{2} & =22,604 \\
p & =0.601\end{aligned}$ \\
\hline Dinlenme odasinda & 352 & 30.6 & 64 & 5.6 & 416 & 36.2 & 108 & 9.4 & 24 & 2.1 & 132 & 11.5 & \\
\hline Tuvalette & 94 & 8.2 & 23 & 2.0 & 117 & 10.2 & 111 & 9.7 & 8 & 0.7 & 119 & 10.3 & \\
\hline $\begin{array}{l}\text { İşletmenin } \\
\text { alanda }\end{array}$ & 37 & 3.2 & 5 & 0.4 & 42 & 3.7 & 385 & 33.5 & 71 & 6.2 & 456 & 39.7 & \\
\hline TOPLAM & 974 & 84.7 & 176 & 15.3 & 1150 & 100.0 & 974 & 84.7 & 176 & 15.3 & 1150 & 100.0 & \\
\hline
\end{tabular}

Katılımcıların eğitim öncesinde \%34.5’inin, eğitim sonrasında ise \% 72.5 'inin ellerini yıkamas1 gereken doğru zamanların tümünde y1kadıkları; \%50.5'inin eğitim öncesinde "mutfak evyesinde", \%76.6'sının eğitim sonrasında "mutfakta el yıkama evyesinde" yıkadıkları tespit edilmiştir. Elde edilen veriler istatistiksel olarak değerlendirildiğinde eğitim öncesi ve eğitim sonrası veriler arasında anlamlı fark bulunmuştur $(\mathrm{p}<0.001)$ (Tablo 3). 
Sormaz, Ü., \& Şanlıer, N. (2017). Zorunlu hijyen eğitiminin yiyecek içecek hizmetleri personelinde hijyen alışkanlıklanına, davranışlarına ve bilgi düzeylerine etkisi. Journal of Human Sciences, 14(2), 1356-1369. doi:10.14687/jhs.v14i2.4545

Katılımcıların eğitim öncesinde \%55.7'sinin ellerini “sıv1 sabun" ile, eğitim sonrasında \%73.7'sinin "dezenfektanlı sıvı" ile y1kadıkları $(\mathrm{p}<0.05)$; eğitim öncesinde \%33.9'unun ellerini yıkadıktan sonra "kurulamadıkları", eğitim sonrasında ise \% 79.9 'unun tek kullanımlık "kağıt havlu" ile kuruladıkları $(\mathrm{p}=0.646)$ belirlenmiştir. Bireylerin \%44.3'ünün eğitim öncesinde periyodik sağlık kontrolü yaptırmadıkları, \%58.5'inin eğitim sonrasında altı ayda bir periyodik sağlık kontrolü yaptırdıkları $(\mathrm{p}=0.557)$ saptanmıştır (Tablo 3).

Tablo 4. Katılımcıların Hijyen Davranışlarının Dağılımı

\begin{tabular}{|c|c|c|c|c|c|c|c|c|c|c|c|c|c|}
\hline \multirow{3}{*}{$\begin{array}{l}\text { PERSONELİN HİJYEN } \\
\text { DAVRANIŞLARI }\end{array}$} & \multicolumn{6}{|c|}{ EĞİTİM ÖNCESİ } & \multicolumn{6}{|c|}{ EĞİTİM SONRASI } & \multirow{3}{*}{$\chi^{2} / \mathbf{P}$} \\
\hline & \multicolumn{2}{|c|}{ Erkek } & \multicolumn{2}{|c|}{ Kadın } & \multicolumn{2}{|c|}{ TOPLAM } & \multicolumn{2}{|c|}{ Erkek } & \multicolumn{2}{|c|}{ Kadın } & \multicolumn{2}{|c|}{ TOPLAM } & \\
\hline & $\mathbf{n}$ & $\%$ & $\mathbf{n}$ & $\%$ & $\mathbf{n}$ & $\%$ & $\mathbf{n}$ & $\%$ & $\mathbf{n}$ & $\%$ & $\mathbf{n}$ & $\%$ & \\
\hline \multicolumn{14}{|l|}{ Mutfakta çalışırken kullanılan iş kıyafeti } \\
\hline Sadece önlük & 137 & 11.9 & 19 & 1.7 & 156 & 13.6 & 76 & 6.6 & 18 & 1.6 & 94 & 8.2 & \multirow{6}{*}{$\begin{aligned} \chi^{2} & =21,872 \\
p & =0.643\end{aligned}$} \\
\hline Sadece aşçı kiyafeti (uzun kollu) & 187 & 16.3 & 36 & 3.1 & 223 & 19.4 & 68 & 5.9 & 15 & 1.3 & 83 & 7.2 & \\
\hline Aşçı kıyafeti ve bone/kep & 295 & 25.7 & 61 & 5.3 & 356 & 31.0 & 84 & 7.3 & 20 & 1.7 & 104 & 9.0 & \\
\hline Aşçı kıyafeti, bone/kep ve galoş & 158 & 13.7 & 31 & 2.7 & 189 & 16.4 & 172 & 15.0 & 21 & 1.8 & 193 & 16.8 & \\
\hline Aşçı kıyafeti, bone/kep, galoş, eldiven & 106 & 9.2 & 14 & 1.2 & 120 & 10.4 & 176 & 15.3 & 34 & 3.0 & 210 & 18.3 & \\
\hline $\begin{array}{l}\text { Aşçı kıyafeti, bone/kep, galoş, eldiven, } \\
\text { maske }\end{array}$ & 91 & 7.9 & 15 & 1.3 & 106 & 9.2 & 398 & 34.6 & 68 & 5.9 & 466 & 40.5 & \\
\hline \multicolumn{13}{|l|}{ İş kıyafetlerini değiştirme sıklığ1 } & \multirow{7}{*}{$\begin{aligned} \chi^{2} & =25.805 \\
p & =0.418\end{aligned}$} \\
\hline Her gün & 148 & 12.9 & 28 & 2.4 & 176 & 15.3 & 468 & 40.7 & 77 & 6.7 & 545 & 47.4 & \\
\hline Günaşırı & 71 & 6.2 & 14 & 1.2 & 85 & 7.4 & 211 & 18.3 & 43 & 3.7 & 254 & 22.1 & \\
\hline Haftada 2 kez & 262 & 22.8 & 46 & 4.0 & 308 & 26.8 & 144 & 12.5 & 25 & 2.2 & 169 & 14.7 & \\
\hline Haftada $1 \mathrm{kez}$ & 402 & 35.0 & 70 & 6.1 & 472 & 41.0 & 101 & 8.8 & 20 & 1.7 & 121 & 10.5 & \\
\hline 15 günde $1 \mathrm{kez}$ & 60 & 5.2 & 15 & 1.3 & 75 & 6.5 & 29 & 2.5 & 6 & 0.5 & 35 & 3.0 & \\
\hline Ayda 1 kez & 31 & 2.7 & 3 & 0.3 & 34 & 3.0 & 21 & 1.8 & 5 & 0.4 & 26 & 2.3 & \\
\hline \multicolumn{13}{|c|}{ Mutfakta çalışırken öksürüp/aksırdığındaki davranışları } & \multirow{6}{*}{$\begin{array}{c}\chi^{2}=29,486 \\
p<0.05\end{array}$} \\
\hline Başını yiyecekten uzağa çevirir & 70 & 6.1 & 16 & 1.4 & 86 & 7.5 & 53 & 4.6 & 10 & 0.9 & 63 & 5.5 & \\
\hline Eliyle ağzını kapatır, ellerini siler & 107 & 9.3 & 22 & 1.9 & 129 & 11.2 & 56 & 4.9 & 6 & 0.5 & 62 & 5.4 & \\
\hline Ağzını ve burnunu mendille kapatır & 449 & 39.0 & 76 & 6.6 & 525 & 45.7 & 52 & 4.5 & 12 & 1.0 & 64 & 5.6 & \\
\hline Eliyle ağzını kapa & 167 & 14.5 & 29 & 2.5 & 196 & 17.0 & 672 & 58.4 & 114 & 9.9 & 786 & 68.3 & \\
\hline Eldiven varsa eldivenini değisştirir & 181 & 15.7 & 33 & 2.9 & 214 & 18.6 & 141 & 12.3 & 34 & 3.0 & 175 & 15.2 & \\
\hline \multicolumn{13}{|c|}{ Elleri yaralandığında mutfakta çalışma durumu } & \multirow{7}{*}{$\begin{array}{l}\chi^{2}=16,201 \\
p=0.909\end{array}$} \\
\hline İyileşene kadar yiyeceklere dokunmaz & 191 & 16.6 & 31 & 2.7 & 222 & 19.3 & 168 & 14.6 & 29 & 2.5 & 197 & 17.1 & \\
\hline Çalışmaya devam eder & 156 & 13.6 & 32 & 2.8 & 188 & 16.3 & 138 & 12.0 & 20 & 1.7 & 158 & 13.7 & \\
\hline Yarayı bantlayıp, çalışmaya devam eder & 568 & 49.4 & 105 & 9.1 & 673 & 58.5 & 137 & 11.9 & 22 & 1.9 & 159 & 13.8 & \\
\hline $\begin{array}{l}\text { Sarg1 beziyle sarıp, çalışmaya devam } \\
\text { eder }\end{array}$ & 24 & 2.1 & 2 & 0.2 & 26 & 2.3 & 87 & 7.6 & 17 & 1.5 & 104 & 9.0 & \\
\hline Eldiven giyip, çalışmaya devam eder & 20 & 1.7 & 4 & 0.3 & 24 & 2.1 & 61 & 5.3 & 15 & 1.3 & 76 & 6.6 & \\
\hline Yarayı bantlayıp, eldiven takarak çalışır & 15 & 1.3 & 2 & 0.2 & 17 & 1.5 & 383 & 33.3 & 73 & 6.3 & 456 & 39.7 & \\
\hline \multicolumn{13}{|c|}{ Hasta olduklarında mutfakta çalışma durumu } & \multirow{5}{*}{$\begin{array}{c}\chi^{2}=4,760 \\
\mathrm{p}=0.855\end{array}$} \\
\hline İşe gelmez & 237 & 20.6 & 37 & 3.2 & 274 & 23.8 & 154 & 13.4 & 28 & 2.4 & 182 & 15.8 & \\
\hline Mutfaktaki işine devam eder & 416 & 36.2 & 67 & 5.8 & 483 & 42.0 & 138 & 12.0 & 18 & 1.6 & 156 & 13.6 & \\
\hline İşe gelir, yiyeceklere dokunmaz & 114 & 9.9 & 28 & 2.4 & 142 & 12.3 & 187 & 16.3 & 42 & 3.7 & 229 & 19.9 & \\
\hline $\begin{array}{l}\text { Doktora gider, tedaviden sonra işe } \\
\text { döner }\end{array}$ & 207 & 18.0 & 44 & 3.8 & 251 & 21.8 & 495 & 43.0 & 88 & 7.7 & 583 & 50.7 & \\
\hline \multicolumn{13}{|c|}{ Mutfakta çalışırken yemeklerin tat kontrolü yapma durumu } & \\
\hline Yapmaz & 127 & 11.0 & 26 & 2.3 & 153 & 13.3 & 50 & 4.3 & 12 & 1.0 & 62 & 5.4 & \\
\hline Eliyle alır & 239 & 20.8 & 38 & 3.3 & 277 & 24.1 & 99 & 8.6 & 19 & 1.7 & 118 & 10.3 & \\
\hline Eldiveni varsa, eliyle alır & 402 & 35.0 & 76 & 6.6 & 478 & 41.6 & 118 & 10.3 & 13 & 1.1 & 131 & 11.4 & $\chi^{2}=301,84$ \\
\hline Ayrı bir tabak, kaşı/ççatalla alır & 127 & 11.0 & 24 & 2.1 & 151 & 13.1 & 466 & 40.5 & 92 & 8.0 & 558 & 48.5 & $\mathrm{p}<0.001$ \\
\hline Pişirmede kullandığı araçlarla alır & 79 & 6.9 & 12 & 1.0 & 91 & 7.9 & 241 & 21.0 & 40 & 3.5 & 281 & 24.4 & \\
\hline TOPLAM & 974 & 84.7 & 176 & 15.3 & 1150 & 100.0 & 974 & 84.7 & 176 & 15.3 & 1150 & 100.0 & \\
\hline
\end{tabular}

Eğitim öncesinde katılımcıların \%31.0'inin çalıșırken sadece "aşçı kıyafeti ve bone" giydikleri, eğitim sonrasında ise $\% 40.5$ 'inin tüm mutfak kıyafetini giydikleri $(\mathrm{p}=0.643)$; kat1lımciların \%41.0'inin eğitim öncesinde iş kıyafetlerini "haftada 1 kez" değiştirirken eğitim sonrasında ise \%47.4'ünün "her gün” değiştirdikleri ( $\mathrm{p}=0.418)$ tespit edilmiştir (Tablo 4). 
Sormaz, Ü., \& Şanlıer, N. (2017). Zorunlu hijyen eğitiminin yiyecek içecek hizmetleri personelinde hijyen alışkanlıklanına, davranışlarına ve bilgi düzeylerine etkisi. Journal of Human Sciences, 14(2), 1356-1369. doi: $10.14687 /$ ihs.v14i2.4545

Katılımcıların eğitim öncesinde \%45.7'sinin mutfakta çalışırken öksürüp/aksırdıklarında "ağzını ve burnunu mendille kapattıkları", eğitim sonrasında ise \%68.3'ünün "elleri ile ağzını kapatıp sonra ellerini yıkadıkları" tespit edilmiştir. Edilen verilere göre eğitim öncesi ve eğitim sonrası yapılan istatistiki değerlendirmede bu sonuç önemli bulunmuştur $(\mathrm{p}<0.05)$ (Tablo 4).

Personelin, eğitim öncesinde \%58.5’inin çalışma esnasında elleri yaralandiğında "yarayı bantlayıp çalısmaya devam ettikleri”, eğitim sonrasında \%39.7'sinin “yarayı bantlayıp, eldiven takarak çalışmaya devam ettikleri", eğitim öncesinde \%42.0'sinin hasta olduklarında "mutfaktaki işine devam ettikleri”, eğitim sonrasında ise \%50.7'sinin "doktora gidip tedavisi bittikten sonra işe döndükleri” tespit edilmiştir. Katılımcıların, eğitim öncesinde \%41.6'sının mutfakta çalışırken tat kontrolünü "eldiven varsa eliyle alarak yaptıkları", eğitim sonrasında ise $\% 48.5$ 'inin tat kontrolünü "ayrı bir tabak, kaşı/ç̧atal ile" yaptıkları belirlenmiştir. Eğitim öncesi ve eğitim sonrası elde edilen sonuç istatistiki olarak anlamlı bulunmuştur $(\mathrm{p}<0.001)$ (Tablo 4).

Katılımcıların "risk grubundaki gidalar" bilgisinin eğitim öncesinde \%82.5'inin yanlış, eğitim sonrasında \%63.7'sinin doğru cevapladıkları; "g1daları tehlikeli isı derecesinde tutmamanın önemi" bilgisinin eğitim öncesinde \%80.5'inin yanlış, eğitim sonrasında \%60.6'sının doğru cevapladıkları; "kuru gıdaların saklandı̆̆ı depoların özellikleri” bilgisinin eğitim öncesinde \%76.3’ünün yanlış, eğitim sonrasında \%71.9’unun doğru cevapladıkları; "g1da güvenliği bakımından yapılması gereken zorunlu uygulamalar" bilgisinin eğitim öncesinde $\% 71.5$ 'inin yanlış, eğitim sonrasında $\% 51.8$ 'inin doğru cevapladıkları; “besin gruplarının saklama dereceleri” bilgisinin eğitim öncesinde \% 75.2 'sinin ve eğitim sonrasında \%50.9’unun yanlış cevapladıkları saptanmıştır.

Edilen verilere göre eğitim öncesi ve eğitim sonrası yapılan istatistiki değerlendirmede; "risk grubundaki gidaları" bilme ( $<<0.05)$, "gidaları tehlikeli 1sı derecesinde tutmamanın önemi” ni bilme $(p<0.001)$, "kuru gidaların saklandığı depoların özellikleri” ni bilme $(p<0.05)$, "gida güvenliği bakımından yapılması gereken zorunlu uygulamalar" 1 bilme $(\mathrm{p}<0.001)$, "besin gruplarının saklama dereceleri”'i bilme durumları ( $\mathrm{p}<0.01)$ önemli bulunmuştur (Tablo 5).

Ayrıca "mutfak için aranan özellikler" bilgisinin eğitim öncesinde $\% 70.3$ 'ünün yanlış, eğitim sonrasında \%51.8'inin doğru cevapladiklar1; "g1da güvenliğini olumsuz etkileyen faktörler" bilgisinin eğitim öncesinde \%78.3'ünün ve eğitim sonrasında \%51.1'inin yanlış cevapladıklar1; "servis sırasında kullanılan araçların hijyen kurallarına göre kullanımı" bilgisinin eğitim öncesinde \%72.9'unun ve eğitim sonrasında \%51.9'unun yanlış cevapladıkları; "sanitasyon kavramının kapsamı" bilgisinin eğitim öncesinde \%76.1'inin yanlış, eğitim sonrasında \%54.9’unun doğru cevapladıkları $(p<0.01)$ bulunmuştur. Edilen verilere göre eğitim öncesi ve eğitim sonrası yapılan istatistiki değerlendirmede; "mutfak için aranan özellikler" i bilme $(p<0.001)$, "g1da güvenliğini olumsuz etkileyen faktörler" i bilme $(\mathrm{p}<0.001)$, "servis sırasında kullanılan araçların hijyen kurallarına göre kullanımı" nı bilme $(p<0.001)$, "sanitasyon kavramının kapsamı" n1 bilme $(p<0.01)$ durumları önemli bulunmuștur (Tablo 5).

Tablo 5. Katılımcıların Hijyen Bilgi Düzeyleri

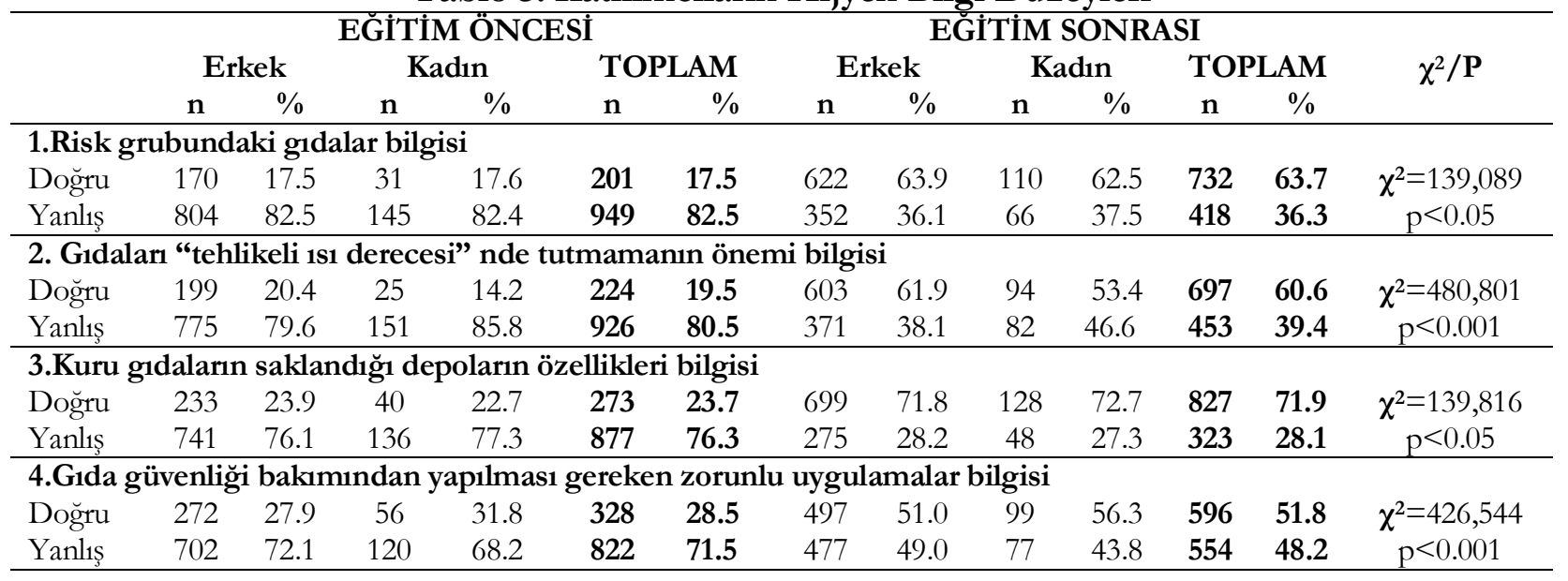


Sormaz, Ü., \& Şanlıer, N. (2017). Zorunlu hijyen eğitiminin yiyecek içecek hizmetleri personelinde hijyen alışkanlıklarına, davranışlarına ve bilgi düzeylerine etkisi. Journal of Human Sciences, 14(2), 1356-1369. doi:10.14687/jhs.v14i2.4545

\begin{tabular}{|c|c|c|c|c|c|c|c|c|c|c|c|c|c|}
\hline \multicolumn{14}{|c|}{ 5.Besin gruplarının saklama dereceleri bilgisi } \\
\hline Doğru & 242 & 24.8 & 43 & 24.4 & 285 & 24.8 & 478 & 49.1 & 87 & 49.4 & 565 & 49.1 & \multirow{2}{*}{$\begin{array}{c}\chi^{2}=392,314 \\
p<0.01\end{array}$} \\
\hline Yanliş & 732 & 75.2 & 133 & 75.6 & 865 & 75.2 & 496 & 50.9 & 89 & 50.6 & 585 & 50.9 & \\
\hline \multicolumn{14}{|c|}{ 6.Mutfak ortamı için aranan özellikleri bilgisi } \\
\hline Doğru & 287 & 29.5 & 55 & 31.3 & 342 & 29.7 & 497 & 51.0 & 99 & 56.3 & 596 & 51.8 & \multirow{2}{*}{$\begin{array}{c}\chi^{2}=452,456 \\
p<0.001\end{array}$} \\
\hline Yanlış & 687 & 70.5 & 121 & 68.8 & 808 & 70.3 & 477 & 49.0 & 77 & 43.8 & 554 & 48.2 & \\
\hline \multicolumn{14}{|c|}{ 7.Gıda güvenliğini olumsuz etkileyen faktörlerin bilgisi } \\
\hline Doğru & 213 & 21.9 & 36 & 20.5 & 249 & 21.7 & 488 & 50.1 & 74 & 42.0 & 562 & 48.9 & \multirow{2}{*}{$\begin{array}{c}\chi^{2}=332,517 \\
\mathrm{p}<0.001\end{array}$} \\
\hline Yanlış & 761 & 78.1 & 140 & 79.5 & 901 & 78.3 & 486 & 49.9 & 102 & 58.0 & 588 & 51.1 & \\
\hline \multicolumn{14}{|c|}{ 8.Servis sırasında kullanılan araçlanın hijyen kurallanına göre kullanımına ilişkin bilgisi } \\
\hline Doğru & 268 & 27.5 & 44 & 25.0 & 312 & 27.1 & 473 & 48.6 & 80 & 45.5 & 553 & 48.1 & \multirow{2}{*}{$\begin{array}{c}\chi^{2}=462,229 \\
p<0.001\end{array}$} \\
\hline Yanlış & 706 & 72.5 & 132 & 75.0 & 838 & 72.9 & 501 & 51.4 & 96 & 54.5 & 597 & 51.9 & \\
\hline \multicolumn{14}{|c|}{ 9.Sanitasyon kavramının kapsamı bilgisi } \\
\hline Doğru & 238 & 24.4 & 37 & 21.0 & 275 & 23.9 & 534 & 54.8 & 97 & 55.1 & 631 & 54.9 & \multirow{2}{*}{$\begin{array}{c}\chi^{2}=297,276 \\
p<0.01\end{array}$} \\
\hline Yanlış & 736 & 75.6 & 139 & 79.0 & 875 & 76.1 & 440 & 45.2 & 79 & 44.9 & 519 & 45.1 & \\
\hline \multicolumn{14}{|c|}{ 10.Gıda hijyeni kavramının kapsamı bilgisi } \\
\hline Doğru & 302 & 31.0 & 60 & 34.1 & 362 & 31.5 & 614 & 63.0 & 108 & 61.4 & 722 & 62.8 & \multirow{2}{*}{$\begin{array}{c}\chi^{2}=313,175 \\
p<0.001\end{array}$} \\
\hline Yanliş & 672 & 69.0 & 116 & 65.9 & 788 & 68.5 & 360 & 37.0 & 68 & 38.6 & 428 & 37.2 & \\
\hline \multicolumn{14}{|c|}{ 11. Gıdalara uygun renklerde doğrama yüzeylerinin kullanım bilgisi } \\
\hline Doğru & 138 & 14.2 & 24 & 13.6 & 162 & 14.1 & 439 & 45.1 & 82 & 46.6 & 521 & 45.3 & \multirow{2}{*}{$\begin{array}{c}\chi^{2}=228,451 \\
p<0.01\end{array}$} \\
\hline Yanliş & 836 & 85.8 & 152 & 86.4 & 988 & 85.9 & 535 & 54.9 & 94 & 53.4 & 629 & 54.7 & \\
\hline \multicolumn{14}{|c|}{ 12.Gıda kaynaklı hastalıklara neden olan maddelerin bilgisi } \\
\hline Doğru & 135 & 13.9 & 28 & 15.9 & 163 & 14.2 & 423 & 43.4 & 83 & 47.2 & 506 & 44.0 & \multirow{2}{*}{$\begin{array}{c}\chi^{2}=241,715 \\
p<0.01\end{array}$} \\
\hline Yanliş & 839 & 86.1 & 148 & 84.1 & 987 & 85.8 & 551 & 56.6 & 93 & 52.8 & 644 & 56.0 & \\
\hline \multicolumn{14}{|c|}{ 13.G1dalanın kontaminasyon nedenleri bilgisi } \\
\hline Doğru & 129 & 13.2 & 21 & 11.9 & 150 & 13.0 & 463 & 47.5 & 89 & 50.6 & 552 & 48.0 & \multirow{2}{*}{$\begin{array}{c}\chi^{2}=186,875 \\
p<0.01\end{array}$} \\
\hline Yanlış & 845 & 86.8 & 155 & 88.1 & 1000 & 87.0 & 511 & 52.5 & 87 & 49.4 & 598 & 52.0 & \\
\hline \multicolumn{14}{|c|}{ 14. Kurubaklagillerin saklanma koşulları bilgisi } \\
\hline Doğru & $184^{\circ}$ & 18.9 & 24 & 13.6 & 208 & 18.1 & 517 & 53.1 & 89 & 50.6 & 606 & 52.7 & \multirow{2}{*}{$\begin{array}{c}\chi^{2}=227,948 \\
p<0.01\end{array}$} \\
\hline Yanlış & 790 & 81.1 & 152 & 86.4 & 942 & 81.9 & 457 & 46.9 & 87 & 49.4 & 544 & 47.3 & \\
\hline \multicolumn{14}{|c|}{ 15.Mutfakta yiyeceklerin g1da güvenliğine uygun olarak hazırlamanın önemi bilgisi } \\
\hline Doğru & 178 & 18.3 & 31 & 17.6 & 209 & 18.2 & 555 & 57.0 & 100 & 56.8 & 655 & 57.0 & \multirow{2}{*}{$\begin{array}{c}\chi^{2}=193,027 \\
p<0.01\end{array}$} \\
\hline Yanlış & 796 & 81.7 & 145 & 82.4 & 941 & 81.8 & 419 & 43.0 & 76 & 43.2 & 495 & 43.0 & \\
\hline
\end{tabular}

Katılımcıların; "gıda hijyeni kavramının kapsamı" bilgisinin eğitim öncesinde \%68,5'inin yanlış, eğitim sonrasında \%62.8'inin doğru cevapladıkları $(\mathrm{p}<0.001)$; "gıda kaynaklı hastalıklara neden olan maddelerin" bilgisinin eğitim öncesinde \%85.8'inin ve eğitim sonrasında \%56.0'sının yanlış cevapladıkları $(\mathrm{p}<0.01)$; "gıdaların kontaminasyon nedenleri" bilgisinin eğitim öncesinde \%87.0'sinin ve eğitim sonrasında \%52.0'sinin yanlış cevapladıkları $(\mathrm{p}<0.01)$ tespit edilmiştir (Tablo $5)$.

\section{TARTIŞMA}

Çocukluk ve gençlik yıllarında kazanılması gereken sağlık alışkanlıklarının ileriki yaşlarda kazandırılması, bu alışkanlıkların davranışa dönüştürülmesini zorlaştırmaktadır (Balaban, 2011; Yurtseven, 2012). Yapılan araştırmada, İngiltere ve Avustralya'da öğrenim gören lise ve üniversite öğrencilerinde hijyen ve gıda hijyeni bilgisinin genel olarak düşük olduğunu tespit edilmiştir (Mullan ve ark., 2015).

Turizm sektöründe yer alan yiyecek içecek bölümlerinin uygun olmayan hijyenik koşullarında üretilen ya da hazırlanan gıda maddeleri tüketime kadar geçen süreç içerisinde çeşitli patojen mikroorganizmaların etkisi ile tüketicilere sağlık yönünden risk oluşturabilecek bir duruma gelebilirler (Ciğerim ve Beyhan, 1994). 29.12.2010 tarih ve 27800 sayılı Resmi Gazete' de yayınlanan Ulusal Meslek Standardı' nda aşçllık mesleğinin tanımı içerisinde "hijyen kurallarına uygun olarak yiyecek hazırlama" ibaresine yer verildiği gibi, aşçllı mesleğinde olması gereken bilgi ve beceriler 
Sormaz, Ü., \& Şanlıer, N. (2017). Zorunlu hijyen eğitiminin yiyecek içecek hizmetleri personelinde hijyen alışkanlıklarına, davranışlarına ve bilgi düzeylerine etkisi. Journal of Human Sciences, 14(2), 1356-1369. doi:10.14687/jhs.v14i2.4545

başlı̆̆1 altında "gıda güvenliği (HACCP, ISO) ile ilgili kurallar bilgisi” (11. madde) ve "hijyen bilgisi” (14. madde), tutum ve davranışlar başlığ1 altında "kişisel bakım ve hijyenine dikkat erme" (20. madde) tanımlamalarına yer vermektedir (UMS, 2010). Bu nedenle, gerek özel şirketlerin kendi kalite standartları gereği aldıkları hijyen eğitimi ve tedbirler ile gerekse devletin getirdiği yasal düzenlemeler ile hijyen eğitiminin son dönemlerde önemi daha da anlaşllmıştır.

Turizm işletmelerinde yiyecek içecek hizmetleri departmanında yaşamsal bir öneme sahip olan hijyen; işletme yöneticileri ve personeli ile yiyecek ve içecek temin eden üreticiler ve aracılar, temizlik malzemesi sağlayanlar ve halk sağlığı uzmanlarının kuracakları işbirliği sonucu hijyenik ortamların oluşturulması yoluyla sağlanabilir (Sökmen, 2003). Doğru hijyen bilgisi ve davranışları, turizm işletmelerinde yiyeceği hazırlayan ve sunan kişilerin, hazırladıkları ve sundukları yiyecekleri kendileri tüketiyormuş gibi özen göstermelerini sağlamaktadır (Yıldırım, 2014). Bu çalışmada mutfak personelinin aldıkları eğitim sonrasında hijyen davranışlarında olumlu yönde değişiklik olduğu tespit edilmiştir. Fuks ve ark. (2004), Sneed ve ark. (2008), Salmon ve ark (2013) tarafindan yapılan çalışmalarda, mutfak personelinde uzun vadeli hijyen davranış değişikliğinin sağlanması için pozitif geribildirimin ve eğitimin sürekliliğinin önemini vurgulamaktadır.

Çalışanların temizliğe dikkat etmesi gereken en önemli yer elleridir. Yiyecekler ne kadar hijyenik olarak depolanmış, hazırlanmış, pişirilmiş veya bekletilmiş olursa olsun, kirli ellerle, kirli araçlarla yapılan servis sırasında yiyeceğe mikroorganizma bulaşabilir (Ünlüönen, 2013). Çalışmada, katılımcıların ellerini yıkamaları gereken doğru zamanda yıkadıkları (eğitimden önce: \%34.5; eğitimden sonra: \%72.5), ellerini eğitimden önce daha çok mutfak evyesinde (\%50.5) ve eğitimden sonra mutfaktaki el yıkama lavabosunda (\%76.6) yıkadıkları, ellerini yıkamak için eğitimden önce s1vı sabunu (\%55.7) ve eğitimden sonra dezenfektanlı sıvıları (\%73.7) kullandıkları, eğitimden önce ellerini yıkadıktan sonra kurulamadıkları (\%33.9) ve eğitimden sonra tek kullanımlık kağıt havlular ile kuruladıkları (\%79.9) saptanmıştır. Srigley ve ark. (2013) ile Salamati ve ark. (2013), hijyen eğitiminin el hijyeninin sağlanmasında en önemli strateji olduğu belirtmektedir. Darko ve ark. (2015) çalışmaya katılan mutfak personelinin \%87.2'sinin ellerini yıkama zamanını doğru olarak bildiklerini belirlemişlerdir.

Tüketiciye güvenilir, temiz, kaliteli ve sağlıklı yiyecek içecek sunulması yoluyla turizm sektöründe yiyecek içecek hizmetleri departmanının başarısının sağlanabildiği unutulmamalıdır (Sökmen, 2003). Ancak bu noktada ön plana çıkan hijyen bilgisi yeterli olmayan bir personel, empati yapsa dahi, hijyenik olmayan bir gida üretimi/sunumuna neden olabilmektedir. Bu nedenle iss tatmini ile empati duygusu artan personelin, aynı zamanda çeşitli eğitimlerle hijyen bilgisinin arttırlması ve sürekli olarak kontrol edilmesi gereklidir (Yıldırım, 2014).

Katılımcıların eğitim öncesinde belirlenen genel hijyen bilgi düzeylerinin ve belirlenen sorulara doğru cevap verme durumlarının eğitim sonrasında önemli ölçüde arttığ1 tespit edilmiştir. Skubina ve Skwierczyński (2007), İngiltere'de otel mutfaklarında çalışan personelin hijyen bilgisini ölçmek amacıyla yürüttügü çalışmada, personelin \%90.0'ının kişisel hijyen konusunda yeterli bilgiye sahip olduğunu belirleme-rağmen, Jevsnik ve ark. (2008), Slovenya'da yaptıkları çalışmada özellikle yiyecek içecek hizmetleri sektöründe çalışan personelin gıda kaynaklı zehirlenmeler hakkında yanlış ve yetersiz bilgiye sahip olduğunu belirtmişlerdir. Neves ve ark. (2007), Portekiz'de mutfak personeli üzerinde yapılan araştırmada personelin hijyen bilgi düzeylerinin yetersiz olduğu tespit etmiştir. Baluka ve ark. (2015) ve Uganda'da, Jeon ve ark. (2015) Güney Kore'de, Tonder ve ark. (2007) Güney Afrika'da yapmış oldukları çalışmada; eğitim düzeyleri yüksek olan katılımcıların hijyen bilgisini öğrenmede, davranışa ve alışkanlığa dönüştürmede diğer gruba göre daha başarılı olduklarını tespit etmişlerdir. Ancak, Lari ve ark. (2006) İran'da yaptıkları çalışmada, gıda üretim işletmelerinde çalışan personelin hijyen bilgi seviyelerinin yüksek olmasına rağmen, bu bilgileri yeteri kadar uygulamaya aktarmadıklarını belirlemiştir. Ayrıca Pang ve ark. (2015) yaptıkları çalışmada, katılımcıların iyi düzeyde hijyen bilgisi ve davranışlarının verilen gida hijyeni eğitiminin alanda verilecek uygulamalarla donatılmasıyla daha olumlu ve kalıcı sonuçlar alındığını vurgulamaktadır. 
Sormaz, Ü., \& Şanlıer, N. (2017). Zorunlu hijyen eğitiminin yiyecek içecek hizmetleri personelinde hijyen alışkanlıklarına, davranışlarına ve bilgi düzeylerine etkisi. Journal of Human Sciences, 14(2), 1356-1369. doi:10.14687/jhs.v14i2.4545

Sonuçta turizm sektörünün yiyecek içecek hizmetleri bölümü çalışanlarına verilen zorunlu hijyen eğitiminin personelin hijyen alışkanlıkları, hijyen davranışları ve hijyen bilgi düzeylerine olan olumlu etkisi tespit edilmiş, ancak;

- Bu olumlu etkinin devam etmesi için zorunlu hijyen eğitimi içeriğinin mevcut programda yer alan sadece teorik bilgi formatından ziyade, teorik ve uygulamalı eğitim olarak yeniden düzenlenmesi,

- Mevcut teorik bilgi formatının hedeflediği "bilgi kazanımı" modeli yerine, teorik ve uygulamalı eğitim formatı ile "hijyen davranış değişikliğinin" sağlanmasının hedeflenmesi,

- 8 saat gibi kısa süresinin daha uzun bir zaman yayılması,

- Eğitimin denetimleri periyodik olarak sağlanması,

- Eğitimin tek sefere mahsus olmayıp periyodik olarak tekrar edilmesi ve devamlılığının sağlanarak kalıcılı̆̆ının arttırılmasının sağlanması,

- Eğitim verecek kişilerin hijyen konularında eğitim almış, alanında uzman personelden oluşturulması,

- Eğitimin sadece turizm sektöründe çalışan yiyecek içecek hizmetleri peroneline değil, aynı zamanda sağlık alanında da çalışan yiyecek içecek hizmetleri personeline ve işletme sahipleri ve yöneticilerine uygulanma zorunluluğu getirilmesi,

önerilebilir.

\section{KAYNAKLAR}

Arboqast, J. W., Moore-Schlitz, L., Jarvis, W. R., Harpster-Haqen, A., Huqhes, J. \& Parker, A. (2016). Impact of a Comprehensive Workplace Hand Hygiene Program on Employer Health Care Insurance Claims and Costs, Absenteeism, and Employee Perceptions and Practices, Journal of Occupational and Enviromental Medicine, 58(6);231-240.

Atasever, M. (2000). Besin İşyerlerinde: Hijyen, Besinlerin Hazırlanması ve Muhafazası, Yü̈züncü Yıl Üniversitesi Veteriner Fakeiltesi Dergisi, 11(2), 117-122.

Balaban, M. (2011). Okul Öncesi Dönemde Hijyen Alışkanlığı Kazandırma Eğitim Programının Çocukların Hijyen Davranışlarına Etkisinin İncelenmesi, Abant İzzet Baysal Üniversitesi Sosyal Bilimler Enstitüsü İlköğretim Okul Öncesi Öğretmenliği Anabilim Dalı, Yüksek Lisans Tezi, Bolu.

Baluka, S. A., Miller, R. A. \& Kaneene, J. B. (2015). Hygiene practices and food contamination in managed food service facilities in Uganda, African Journal of Food Science, 9 (1); 31-42.

Baş, M., Ersun, A. Ş. \& Kivanç, G. (2006). The Evaluation of Food Hygiene Knowledge, Attitudes, and Practices of Food Handlers' in Food Businesses in Turkey, Food Control, 17(4), 317-322.

Büyüköztürk, S.. (2004). Sosyal bilimler için veri analizi el kitabı, Pegem Yayıncılık, 195 s., Ankara.

CDC (2002). Centers for Disease Control and Prevention, Guideline for Hand Hygiene in Health-Care Settings Recommendation of the Healthcare Infection Control Practices Advisory Committee and the HICPAC/SHEA/APIC/IDSA Hand Hygiene Task Force. MMWR, 51(No.RR-16). Erişim Tarihi: 25.08.2015.

Ciğerim, N. \& Beyhan, Y. (1994). Toplu beslenme sistemlerinde hijyen. Kök Yayıncılık, 47 s, Ankara.

Clayton, D. A., Griffith, C. J., Price, P. \& Peters, A. C. (2002). Food Handlers Beliefs and Self-Reported Practices, International Journal of Environmental Health Research, 12, 25-39.

Darko, S., Mills-Robertson, F. C. \& Wireko-Manu, F. D. (2015). Evaluation of some hotel kitchen staff on their knowledge on food safety and kitchen hygiene in the Kumasi Metropolis, International Food Research Journal, 22(6); 2664-2669.

Domínguez, C., Gómez, I. \& Zumalacárregui, J. (2002). Prevalence of Salmonella and Campylobacter in retail chicken meat in Spain, International Journal of Food Microbiology, (72):165-168.

Eksen, M., Karadağ, N. \& Karakuş, A. (2004). Muğla merkez ilçe gıda işyerlerinde çalışanların el ve vücut hijyeni konusundaki bilgi düzeylerinin incelenmesi, $U G B D, 1(1): 1-21$. 
Sormaz, Ü., \& Şanlıer, N. (2017). Zorunlu hijyen eğitiminin yiyecek içecek hizmetleri personelinde hijyen alışkanlıklarına, davranışlarına ve bilgi düzeylerine etkisi. Journal of Human Sciences, 14(2), 1356-1369. doi:10.14687/jhs.v14i2.4545

Eymen, U. E. (2007). SPSS 15.0 veri analiz yöntemleri, Erişim Tarihi: 01.12.2012, www.istatistikmerkezi.com

Fuks, M. M., Szteyn, J. \& Wiszniewska, A. (2004). Many depends on people, Bezpieczeństwo i Higiena Żywności, 15(4):38-39.

Issa, M., McHenry, M. , Issa, A. A. \& Blackwood, R. A. (2015). Access to Safe Water and Personal Hygiene Practices in the Kulandia Refugee Camp (Juresalem), Infectious Disease Reports, 7(4); 8186.

İslamoğlu, A. H. \& Alnıaçık, Ü. (2014). Sosyal bilimlerde araştırma yöntemleri (spss uygulamalı). İstanbul, Beta Yayıncilik.

Jeon, M. S., Park, S. J., Jang, H. J., Choi, Y. S. \& Hong, W. S. (2015). Evaluation of sanitation knowledge and practices of restaurant kitchen staff in South Korea, British Food Journal, 117 (1); 62-77.

Jevsnik, M., Hlebec, V. \& Raspor, P. (2008). Food safety knowledge and practices among food handlers in Sloveni, Food Control, 19: 1107-1118.

Kalaycı, Ş. (2009). SPSS uygulamalı çok değişkenli istatistik teknikleri. Ankara, Asil Yayınevi.

Karasar, N. (2003). Bilimsel araştırma yöntemi. Ankara, Nobel Yayın Dağıtım.

Koçoğlu, G., Sümer, H., Nur, N. \& Polat, H. (2004). Gıda Maddesi Üreten ve Satan Yerlerde Çalışanların Sanitasyon Konusunda Bilgi Düzeyleri, C. Ü. Halk Sağlığı A.D. Sivas.

Kozak, M., Çakıcı, C., Kozak, N., Azaltun, M., Sökmen, A., Sarışık, M. \& Çetinsöz, B.C. (2008). Otel İşletmeciliği, (2.Baskı), Detay Yayıncıllk, Ankara.

Lari, M. A., Soodbakhsh, S. \& Lakzadeh, L. (2006). Knowledge, attitudes and practices of workers on food hygienic practices in meat processing plants in Fars, Iran, Food Control, 21: 260-263.

Lucca, A. \& Torres E. A. F. S. (2006). Street Food: The Hygiene Conditions of Hot-Dogs in Sao Paulo, Brazil, Food Control, 17(4), 312-316.

MEB (2013). Milli Eğitim Bakanlığı, Hayat Boyu Öğrenme Genel Müdürlüğü, Yiyecek İçecek Hizmetleri Et ve Et Ürünleri İşletmeciliği Hijyen Eğitimi, Modüler Programı (Yeterliliğe Dayalı), Ankara.

Memiş, E. (2009). Ortaöğretim Kurumlarının Yemekhanelerinde Çalışan Personelin, Öğrencilerin ve Öğretmenlerin Gıda Güvenliği Konusunda Bilgi ve Tutumları, Gazi Üniversitesi, Eğitim Bilimleri Enstitüsü, Ev Ekonomisi Bölümü, Aile Ekonomisi ve Beslenme Eğitimi Anabilim Dalı, Aile Ekonomisi ve Beslenme Eğitimi Bilim Dalı, Doktora Tezi, Ankara.

Mullan, B. A., Wong, C., Todd, J., Davis, E. \& Kothe, E. J. (2015). Food hygiene knowledge in adolescents and young adults, British Food Journal, 117 (1); 50-61.

Neves, E. G., Araújo, A. C., Ramos, E. \& Cardoso, C. S. (2007). Food handling: Comparative analysis of general knowledge and practice in three relevant groups in Portugal, Food Control, 18: 707712.

Pang, J., Chua, S. W. J. L. \& Hsu, L. (2015). Current knowledge, attitude and behaviour of hand and food hygine in a developed residential community of Singapore: a cross-sectional survey, BioMed Central Public Health, 15:577.

Salamati, P., Poursharifi, H., Rahbarimanesh, A. A., Koochak, H. E. \& Najafi, Z. (2013). Effectiveness of Motivational Interviewing in Promoting Hand Hygiene of Nursing Personnel, International Journal of Preventive Medicine, 4 (4): 441-447.

Salmon, S., Wang, X. B., Seetoh, T., Lee, S. Y. \& Fisher, D. A. (2013). A Novel approach to improve hand hygiene compliance of student nurses, Antimicrobial Resistance and Infection Control, 2:16. Erişim Tarihi: 01.11.2015, http://www.aricjournal.com/content/pdf/2047-2994-2-16.pdf.

Sansam, S., Yamamoto, E., Srun, S., Sinath, Y., Moniborin, M., Bun, S. K., Reyer, J. A., Yoshida, Y. \& Hamajima, N. (2016). Assessment of hand hygiene compliance after hand hygiene education among health care workers in Cambodia, Nagoya Journal of Medical Science, 78(2): 151-162.

Skubina, C. E. \& Skwierczyński, S. (2007). Examination of hygiene knowledge of personnel employed in hotel caternng establishments, Polish Journal of Food and Nutrition Sciences, 57(4): 95-99.

Sneed, J., Strohbehn, C. H. \& Beattie, S. (2008). Impact of employee training on mitigating contamination in retail food service operations, Current Research Information System (CRIS), Project Number: IOWW-2005-02091. 
Sormaz, Ü., \& Şanlıer, N. (2017). Zorunlu hijyen eğitiminin yiyecek içecek hizmetleri personelinde hijyen alışkanlıklarına, davranışlarına ve bilgi düzeylerine etkisi. Journal of Human Sciences, 14(2), 1356-1369. doi:10.14687/jhs.v14i2.4545

Sökmen, A. (2003). Ağırlama Endüstrisinde Yiyecek ve İçecek Yönetimi. (1.baskı). Ankara: Detay yayincilik.

Srigley, J. A., Lightfoot, D., Fernie, G., Gardam, M. \& Muller, P. M. (2013). Hand hygiene monitoring technology: protocol for a systematic review, Systematic Reviews, 2:101. Erişim Tarihi: 01.11.2015, http://www.systematicreviewsjournal.com/content/2/1/101.

Şanlier, N. (2009). The knowledge and practice of food safety by young and adult consumer, Food Control, 20 (6); 538-542.

Şanlier, N., Cömert, M. \& Durlu-Özkaya, F. (2010). Hygiene perception conditions of hotel kitchen staff in Ankara, Turkey, Journal of Food Safety, 30 (2); 415-431.

Tayar, M. (2011), Hijyen ve Sanitasyon, Anadolu Üniversitesi, Açıöğretim Fakültesi Yayınları, No: 1346, Eskişehir.

Temelli, S. (2002). G1da zehirlenmesine neden olan E. coli O157: H7 ve önemi, Uludă̆ Üniversitesi Veteriner Fakültesi Dergisi, (21): 133-138.

Thakker, V. S. \& Jadhav, P. R. (2015). Knowledge of hand hygiene in undergraduate medical, dental, and nursing students: A cross-sectional survey, Journal of Family Medicine and Primary Care, 4(4); 582-586.

Theriault, F. M., Blouin, B., Casapia, M. \& Gyorkos, T. W. (2015). Sustaining a hygiene education intervention to prevent and control geohelminth infections at school in the Peruvian Amazon, Revista Panamericana Salud Publica, 38(4): 344-346.

Tonder, I., Jan, F. R. \& Theron, M. M. (2007). The personal and general hygiene practices of food handlers in the delicatessen sections of retail outlets in South Africa, Journal of Environmental Health, 27-31.

UMS (2010). Ulusal Meslek Standardı, Mesleki Yeterlilik Kurumu, Aşçı (seviye 4), Referans Kodu: 10UMS0110-4, Erişim Tarihi: 05.12.2016, Erişim Adresi: http://portal.myk.gov.tr/index.php?option=com_meslek_std_taslak\&view=taslak_listesi_yeni \&msd $=2$.

Ural, A. \& Kılıç, G. (2013). Bilimsel Araştırma Süreci ve SPSS ile Veri Analizi. (4. Baskı). Ankara: Detay Yayıncilik.

Ünlüönen, K. ve Cömert, M. (2013). Otel İşletmeleri Mutfak Çalışanlarının Personel Hijyeni Bilgi Düzeylerinin Belirlenmesi, Joumal of Tourism and Gastronomi Studies, 1(1); 3-12.

WHO (2006a). World Health Organization, Guidelines for Hand Hygiene in Health Care - Global Patient Safety Challenge 2005 2006: Clean care is safer care. Erişim Tarihi: 28.08.2015, http://www.who.int/patientsafety/events/05/GPSC_Launch_ENGLISH_FINAL.pdf

WHO (2006b). World Health Organization, Globalization, Trade and Health, Glossary of Terms, Erişim Tarihi: 28.08.2015, http.//www.who.int / trade/glossary / story 027/en/index.html

Yıldıım, E. (2014). Konaklama İşletmelerinde Mutfak ve Servis Personelinin İş Tatmini İle Kişisel Hijyen Bilgi ve Uygulamalan, Gazi Üniversitesi, Eğitim Bilimleri Enstitüsü, Aile Ekonomisi ve Beslenme Eğitimi Anabilim Dalı, Yüksek Lisans Tezi, Ankara.

Yurtseven, A. (2012). Eğitim Uygulama Okullar1 ve Rehabilitasyon Merkezlerindeki Öğretilebilir Zihinsel Engelli Bireylerin Kişisel Hijyeni İle İlgili Uygulamalar ve Velilerinin Bilgileri, Gazi Üniversitesi, Eğitim Bilimleri Enstitüsü, Aile Ekonomisi ve Beslenme Eğitim Anabilim Dalı, Yüksek Lisans Tezi, Ankara.

\section{Extended English Abstract}

Hygiene, an important issue in all aspects of human life, is also of utmost importance for businesses. Consumers are gaining more and more awareness and education on hygiene, services by food and beverage businesses are offered in a clean, careful way, suitable to the aesthetical values taking into consideration hygiene regulations. As a result, hygiene is one of the top expectations of consumers and is seen as an indicator of quality (Tayar, 2011). Similarly, as well as the care given to personnel hygiene, it also needs to be paid attention that clothes and other stuff like hats, bonnets, aprons, gloves, masks, etc. put on at work should be kept clean (Atasever, 2000). 
Sormaz, Ü., \& Şanlıer, N. (2017). Zorunlu hijyen eğitiminin yiyecek içecek hizmetleri personelinde hijyen alışkanlıklarına, davranışlarına ve bilgi düzeylerine etkisi. Journal of Human Sciences, 14(2), 1356-1369. doi:10.14687/jhs.v14i2.4545

This study has been conducted to investigate the impact of the compulsory hygiene education offered to the staff working in food and beverage services on their hygiene-related behaviors.

\section{METHODOLOGY}

1150 volunteer staff working in food and beverage services who had attended the hygiene education offered in İstanbul during the period of February $1^{\text {st }}$ - October 1st, 2015 participated in the study. Prior to and after the study, the participants were applied questionnaires proved to be valid and reliable being used in previous studies and consisting of 4 sections and 23 questions, to detect their demographic features, the characteristics of their workplaces, their hygiene-related habits and behaviors, using the face-to-face interview technique (Şanlıer, 2009; Memiş, 2009; Şanlıer et al., 2010).

\section{FINDINGS}

A total number of 1150 food and beverage services staff working in the tourism sector in İstanbul, 176 females $(15,3 \%)$ and 974 males $(84,7 \%)$, participated in the study. It has been discovered that $30,3 \%$ of those participated in the study are primary school graduates, $28,6 \%$ are secondary school graduates, $49,0 \%$ have not received any vocational training; and that $29,0 \%$ have been working in the sector for $11-20$ years, and $26,1 \%$ for less than 5 years.

It has been observed that $73,9 \%$ of these staff are working at hotels, $26,1 \%$ at restaurants, $29,3 \%$ at 5 -star hotels, $46,7 \%$ at kitchen departments, and $52,6 \%$ at international businesses. $74,1 \%$ of the participants have expressed that there are not any social areas belonging to the department of food and beverage services at where they work, $46,9 \%$ that they have not received any kind of in-service education, and $17,0 \%$ that they have received food safety and hygiene education.

The study has found out that while $31,0 \%$ of the participants wear only chef coats and bonnets before the education, $40.5 \%$ of the participants start to wear all kinds of kitchen clothing after the education ( $\mathrm{p}=0.643)$; and that while $41,0 \%$ change their work uniforms only once a week, $47,4 \%$ start to change 'everyday' after the education ( $\mathrm{p}=0.418$ ). Moreover, before the education $45,7 \%$ of the participants cover their mouth and nose when they sneeze or cough, and 68,3\% start to cover their mouth and nose and then wash their hands when they sneeze or cough after the education. This outcome is considered to be statistically significant according to the gathered data $(\mathrm{p}<0.05)$.

\section{DISCUSSION}

Foods produced and prepared under inappropriate hygiene conditions at departments of food and beverage services can evolve into a situation that would cause serious health risks to consumers by the influence of various pathogenic microorganisms until they are consumed (Ciğerim \& Beyhan, 1994). Therefore, the emphasis on hygiene and attention paid to it have increased recently both thanks to the hygiene education and measures private companies perform within the scope of their own quality standards and principles, and also by official regulations put into force by the government. The participants are working at departments of food and beverage services in the tourism sector, and 176 females $(15,3 \%)$, and 974 males $(84,7 \%) .52,6 \%$ of the participants are working at international chain enterprises, $29,3 \%$ at 5 -star hotels, and $46,7 \%$ at kitchen departments; 30,3\% are primary school graduates, $49,0 \%$ have not received any vocational education, and $46,9 \%$ have not received any culinary in-service education, either.

To sum up, the compulsory hygiene education given to the personnel working at food and beverage services in the tourism sector has positive effects on personnel's hygiene-related behaviors, habits and knowledge; however, in order for these positive effects to maintain, the content and scope of the compulsory hygiene education should be reformed being enriched with applications; the current time for this is only 8 hours, more time should be allocated and it should be spread over a longer period of time rather than a one-time training; and it is suggested that its permanency be increased ensuring its maintenance. 